Jurnal Pena Sains Vol. 5, No. 1, April 2018

\title{
THE DEVELOPING OF SIMPLE PROPS BASED ON GUIDED INQUIRY TO IMPROVE STUDENTS' CRITICAL THINKING SKILL'S
}

\author{
Desi Eka Nur Setyaningsih $^{1}$ and Astuti Wijayanti ${ }^{2}$ \\ ${ }^{1}$ Natural Science Education Study Program, Faculty of Teacher Training and Education \\ University of Sarjanawiyata Tamansiswa \\ Yogyakarta, 55165, Indonesia \\ desiekanur@gmail.com \\ ${ }^{2}{ }^{1}$ Natural Science Education Study Program, Faculty of Teacher Training and Education \\ University of Sarjanawiyata Tamansiswa \\ Yogyakarta, 55165, Indonesia \\ astuti.wijavanti.@ustiogja.ac.id
}

\begin{abstract}
This research is aimed to 1) develop simple props based on guided inquiry. 2) know the implementation of simple props based on guided inquiry.3) know students' critical thinking skill by using simple props. This research is research and development with 4D models. The average score in an aspect based on the whole result of the assessment by media expert is $99,33 \%$, the material expert is $88,20 \%$, peer reviewer $83,02 \%$, and science teacher upon the simple props is $88,41 \%$, then it can be stated as good. There is an improvement in the student's result when doing pretest and posttest. The average score of the students when doing pretest is 5,29 , and posttest is 7,9. The level of critical thinking skill of the students is on the level medium with the gain score is 0,54 .
\end{abstract}

Keywords: Critical thinking skill, Guided Inquiry, Simple Props 


\section{Introduction}

Development of science and technology so quickly demanded the teacher to more creative and skilled in order for students to have the competitiveness and to deal with changes in life in a world that is always evolving. Education is one of the very important factors in the role of quality so manifest a human able to deal with the development of science and technology. Education was also seen as a means to give birth to a character, healthy, intelligent, creative, skilled, responsible, productive, and ethical sublime.

Education is, in fact, a conscious effort and planned to bring about an atmosphere of learning and the learning process so that students are actively developing the potential in him. The future of the nation of Indonesia in addition determined by natural resources is also determined by the quality of the human resources themselves. Attempts to form an intelligent human/learned and quality, as well as good personality, is part of the educational mission of the professional responsibility of every teacher. As according to Poedjiadi in Lestari (2013) says that the learning process of transferring the science, but also capable of assisting the process of understanding the subject matter through the selection of the model as well as the use of appropriate learning with media the development of science and technology at this time.

Learning props or Media gave a great influence towards the students, particularly the level of junior high school students. Junior high school students ware about 11-14 years old. According to Piaget in Fatima Ibda (2015) age, 11 or 12 years up to adults are on the formal operational stage. At this stage, students are able to think and build an understanding of knowledge related to concrete reality.
Concrete objects can give a deeper impression on students with the goal of students will better remember what had he learned. According to Widiyatmoko (2013) props is defined as a tool to educate or teach teacher taught so that the concept is easy to understand by students and become a tool in the learning process that is created by the teacher or students from simple materials are easily obtainable from the surrounding environment.

Based on the results of observation of the researchers who performed in junior high Country 2 Imogiri in mind that learning science at that school has not been able to maximize the critical thinking skills of students. According to Johnson in the Treasury (2017) critical thinking is a process that is directional and clearly used in mental activities like solving problems, decisions, persuade, analyze assumptions, and conducting scientific research. Critical thinking is the ability to apply the ratio, high thinking activities, including activities to analyze, synthesize, know the problems, and solving them, conclude, and evaluating. But in reality, while doing practical work, students already interested and excited, but students still have not been able to draw your own conclusions about the practice results. Therefore, students still need guidance in making conclusions and need a guidebook props as a guide to its use, namely through guided inquiry. According to Eggen (2012), guided Inquiry is one approach to teaching where the teacher gives students examples of specific topics and guide the students to understand the topic.

Learning science using guided inquiry can make students active in discovering science concepts. The task of the teacher in the guided inquiry learning, i.e. as a facilitator. Learning-based guided inquiry can be implemented by using the methods of questioning, discussion, demonstrations, or laboratory activities. 
Method of guided inquiry conducted by a laboratory or practical activities, positioning students as though as scientists who did one experiment in an attempt to find the relationship of natural phenomena. According to Sudjana (Trianto, 2014) States there are six stages of Guided Inquiry, namely: 1) presents a question or a problem, 2) make a hypothesis, 3) designing experiments, 4) experiment to obtain information, 5) collect and analyze data, 6) make a conclusion.

One of the constraints in the practical activities of the science that is in desperate need of a lot of instrument. But the perception of teachers against props is generally expensive. According to Asyhar (2012) media is learning everything it can convey or transmit messages from a source programmatically so that conducive learning environments occur where the recipient can do the learning process is efficient and effective. Simple props can be made in accordance with the concept of the material to be taught the gan utilizes materials that are in the environment, without having to spend a lot of costs. Furthermore, in the operation of the simple instrument is not need something specific skills. In accordance to Widiyatmoko (2013), that the science instrument can be made with the cheaps material, like reusable material.

Using instruments in the learning process is expected to help teachers demonstrate natural science concepts. It makes that students understand the concepts more easily. Such statements Sidharta (2013) that the use of natural science instruments can help teach natural science concept becomes more meaningful. Moreover, according to Prasetyarini (2013) that learning with the use of instruments is a series of activities for delivering the subject matter aimed at giving students opportunities for active learning, allowing students gain knowledge and train their creative problem-solving ability.

Instruments and/media of natural science where there in the school is limited. Based on that, then students should alternately use the tool. This resulted in a large number of wasted time to wait their turn to practical work, while no directional communication in lessons. The limitation of the number of means of practical science needs to be addressed by giving the students to learn the same material using alternative media. Based on the above description, as for the formulation of the problem in this study i.e. how to develop a physic instrument based guided inquiry to improve critical thinking skills of students of grade VIII SMP Negeri 2 Imogiri?

\section{Research Methods}

This research was carried out during the six months from November 23, 2016, until may 30, 2017 on the even semester, academic year 2016/2017. This research was conducted at the SMPN 2 Imogiri. The subject in this study was validtion by 1 lecturer media expert, 6 peer reviewer, 6 teacher science, and students and object in the research is physic instrument based guided inquiry learning to improve critical thinking skills of students.

This research includes the development of this type of research. The model research and development used IE 4-D model suggested by Thiagarajan, et al. (Trianto, 2014) is a model 4-D. The model consists of four stages of development, that is, Define, Design, Develop, and Disseminate (figure 1). Total population of grade VIII in SMP Negeri 2 Imogiri as much as 180 students. The sample used in the amount of $10-15 \%$ i.e. as many as 24 students. Students give assessments and feedback as the basis for the final revision of the top and the subject matter was 
teaching with the instrument is hydrostatic pressure.

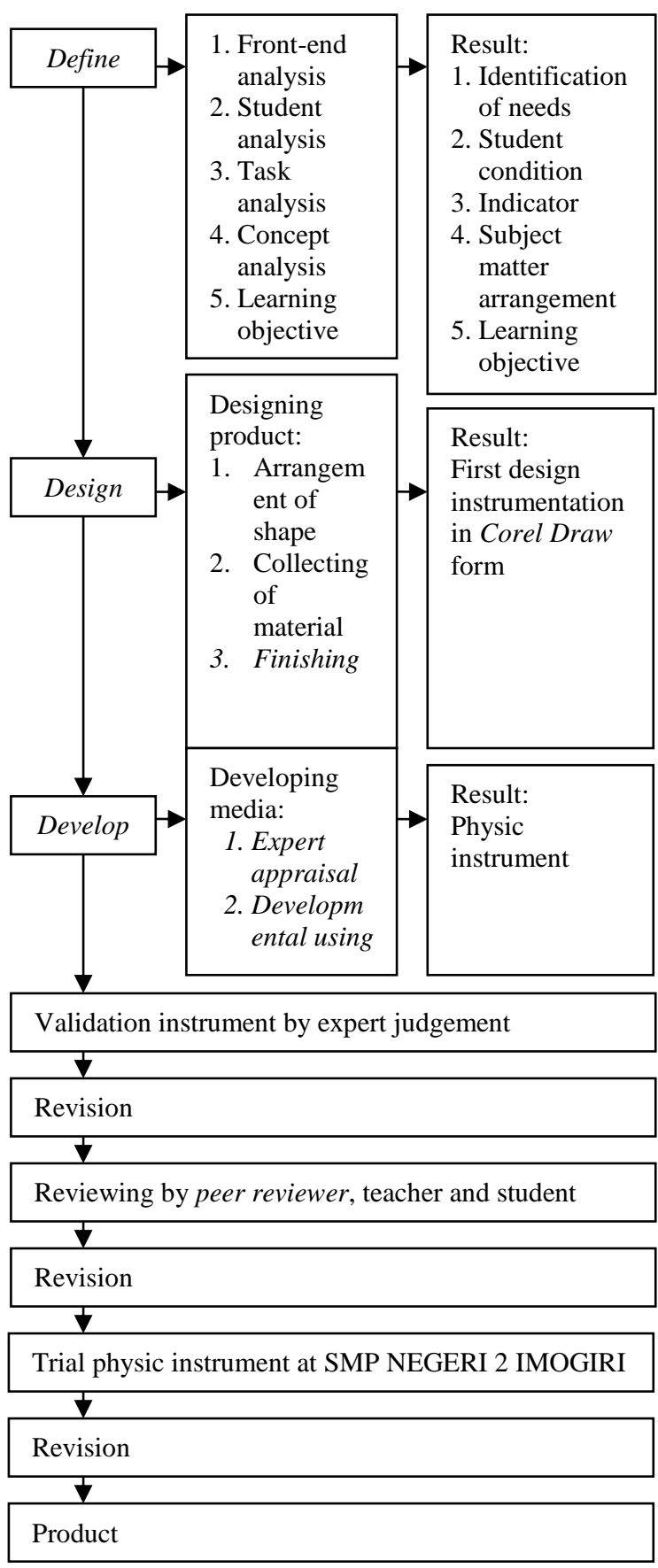

Figure 1. Scheme of 4D models

\section{Result and Discussion}

This research aims are developing science simple props-based guided inquiry so as to enhance the critical thinking skills of students of grade VIII SMP Negeri 2 Imogiri. Science simple props is developed using the model $4 \mathrm{~d}$ (Rosidi, 2015). This study only up to at this stage of testing is limited and does not do the empirical test/field test to see its effect on students. Props is assessed from a variety of input from media experts and expert material is then used to fine-tune the Science props simple so that the resulting product revision I of science simple props. Some feedback from the reviewer that follow up on the following table:

Table 1. Follow-up over the input media

\begin{tabular}{cll}
\multicolumn{2}{c}{ expert } \\
\hline No. & \multicolumn{1}{c}{ Input } & \multicolumn{1}{c}{ Follow-up } \\
\hline 1 & $\begin{array}{l}\text { Tools in order to } \\
\text { be repaired }\end{array}$ & $\begin{array}{l}\text { Props repaired so that it } \\
\text { becomes clearer. }\end{array}$ \\
2 & $\begin{array}{l}\text { Give the scale on } \\
\text { props }\end{array}$ & $\begin{array}{l}\text { Props have already been } \\
\text { given the scale of the } \\
\text { laminating with the } \\
\text { paper so that the scale } \\
\text { does not disappear when } \\
\text { exposed to water. }\end{array}$
\end{tabular}

3 Extended interval The size of the hose is already extended to be able to get into the base of sump water.

$4 \quad$ Writing cycles

The writing had already been clarified so that all students can see clearly.

$5 \quad$ For tub shelter marked with this type of solution and given the scale

The sump was given the writings of salt solutions and solution of water wells and sump each were given a scale with a distance of $1 \mathrm{~cm}$.

6 The rubber membrane or in order to look

Replace the rubber membrane or stronger. stronger 
Table 2. Follow-up over the input of expert

material

\begin{tabular}{lll}
\hline No. & \multicolumn{1}{c}{ Input } & \multicolumn{1}{c}{ Follow-up } \\
\hline 1. & $\begin{array}{l}\text { The equipment } \\
\text { is already pretty } \\
\text { good and can be } \\
\text { implemented on } \\
\text { learning at grade } \\
\text { VIII }\end{array}$ & $\begin{array}{l}\text { Further enhanced by } \\
\text { developing more }\end{array}$ \\
& $\begin{array}{l}\text { Understanding } \\
\text { the concept of } \\
\text { the pressure on } \\
\text { the liquid needs } \\
\text { to be examined } \\
\text { more in }\end{array}$ & $\begin{array}{l}\text { Understanding the concept } \\
\text { is already adapted to the } \\
\text { concept of the pressure of } \\
\text { the liquid so that it does } \\
\text { not cause the } \\
\text { misconception }\end{array}$ \\
\hline
\end{tabular}

Table 3. Follow-up from peer reviewers

\begin{tabular}{lll} 
No. & \multicolumn{1}{c}{ Input } & \multicolumn{1}{c}{ Follow-up } \\
\hline 1. & $\begin{array}{l}\text { Props are in } \\
\text { compliance with } \\
\text { the material, very } \\
\text { simple and easy to } \\
\text { use so that students } \\
\text { can easily } \\
\text { understand the } \\
\text { concept of the } \\
\text { given }\end{array}$ & $\begin{array}{l}\text { More enhanced } \\
\text { the development } \\
\text { of the work }\end{array}$ \\
\hline
\end{tabular}

Table 4. Follow up feedback from teachers and students

\begin{tabular}{|c|c|c|}
\hline No. & Input & Follow-up \\
\hline 1. & $\begin{array}{l}\text { Worksheet needs conclusions to } \\
\qquad P=\rho \times g \times h\end{array}$ & $\begin{array}{l}\text { On worksheet already is written conclusions to } \\
P=\rho \times g \times h\end{array}$ \\
\hline 2. & $\begin{array}{l}\text { On the jar tool (sump) led to show its depth } \\
\text { made vertical }\end{array}$ & $\begin{array}{l}\text { Students already are guided in determining the } \\
\text { depth to create vertical }\end{array}$ \\
\hline 3. & $\begin{array}{l}\text { U pipe is too large, so in depth that small yet } \\
\text { can show the difference in the liquid in the } \\
\text { pipe U clearly }\end{array}$ & $\begin{array}{l}\text { U already scaled down so that the pipe at a depth } \\
\text { which is small already could show a difference in } \\
\text { the liquid in the pipe } U\end{array}$ \\
\hline 4. & $\begin{array}{l}\text { Liquid depth scale (h) should be made from } \\
\text { the top surface of the liquid to the bottom }\end{array}$ & $\begin{array}{l}\text { The scale of the depth of the liquid made from } \\
\text { above the surface of the liquid to the bottom }\end{array}$ \\
\hline 5. & $\begin{array}{l}\text { Color appearance made more contrast so it } \\
\text { can be seen from the distance a bit far when } \\
\text { for a demonstration }\end{array}$ & $\begin{array}{l}\text { The color of the display contrast is already made so } \\
\text { it can be seen from a distance when for a } \\
\text { demonstration }\end{array}$ \\
\hline 6. & $\begin{array}{l}\text { The placement of the clamps do not cover the } \\
\text { surface of the water }\end{array}$ & $\begin{array}{l}\text { The placement of the clamp is not already cover the } \\
\text { surface of the water }\end{array}$ \\
\hline 7. & $\begin{array}{l}\text { The scale is made more thoroughly by using a } \\
\text { ruler }\end{array}$ & $\begin{array}{l}\text { The scale was made more thoroughly by using a } \\
\text { ruler }\end{array}$ \\
\hline 8. & $\begin{array}{l}\text { Lower holder made wider so that the scale be } \\
\text { balanced boards }\end{array}$ & $\begin{array}{l}\text { The stand down was made wider so the scale } \\
\text { becomes balanced boards }\end{array}$ \\
\hline 9. & $\begin{array}{l}\text { The making of the props basically already } \\
\text { well could've been used as a medium for } \\
\text { teaching and learning activities, but still, } \\
\text { there must be improvements to be used } \\
\text { properly. }\end{array}$ & More enhanced the development of the work \\
\hline 10. & $\begin{array}{l}\text { Installation of the pipes do not have bent } \\
\text { parts }\end{array}$ & The pipe is already installed with no bent parts \\
\hline
\end{tabular}

This revision phase formative evaluation included for perfecting products that have been developed, evaluation is used at any stage i.e. the definition, design, development, and determination.

The quality of the science props that have been compiled knowable by way of 
analyzing the data obtained based on an assessment of the reviewer. Reviewers consist of media experts, expert content, peer reviewers, teachers and students. Data analysis is done by changing the qualitative data obtained from the assessment reviewers into quantitative data with calculations as shown in the annex. The quantitative data are tabulated and analyzed every aspect of the assessment. The final score is obtained, converted into a qualitative assessment based on criteria the category ideal. The following quality simple props-based guided inquiry based on expert assessment material, media experts, peer reviewers, teachers and student response.

Assessment of every aspect on the basis of accumulated based on the percentage of each aspect can be seen in Figure 2.

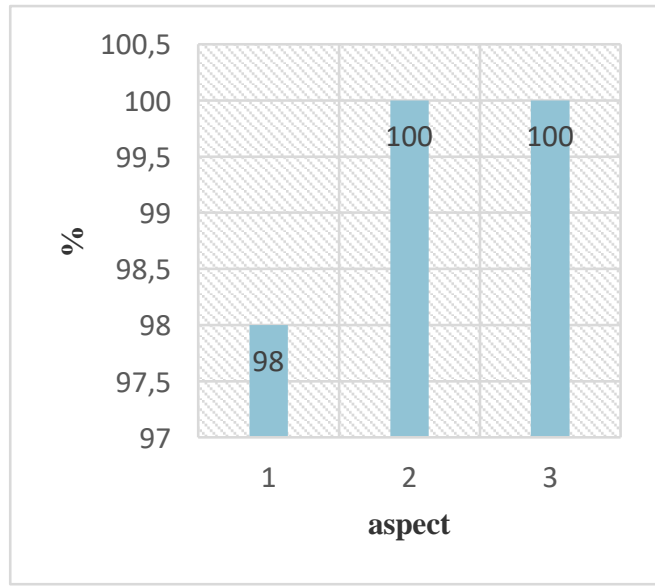

Figure 2. Percentage of ideality each aspect of prop validation results from media experts

Description:

1. The quality of the props

2. Aspects of conformity science simple props with the material pressure

3. Aspects of compliance science simple props with curricula on the material pressure
In the figure 2 , clearly visible aspects of a balanced assessment are the second aspect and the third aspect, has a percentage of $100 \%$, then the number one aspect of $98 \%$. Thus, the results of the assessment by media experts stated that props has generated in very good quality.

Assessment of every aspect on the basis of accumulated based on the percentage of each aspect can be seen in Figure 3.

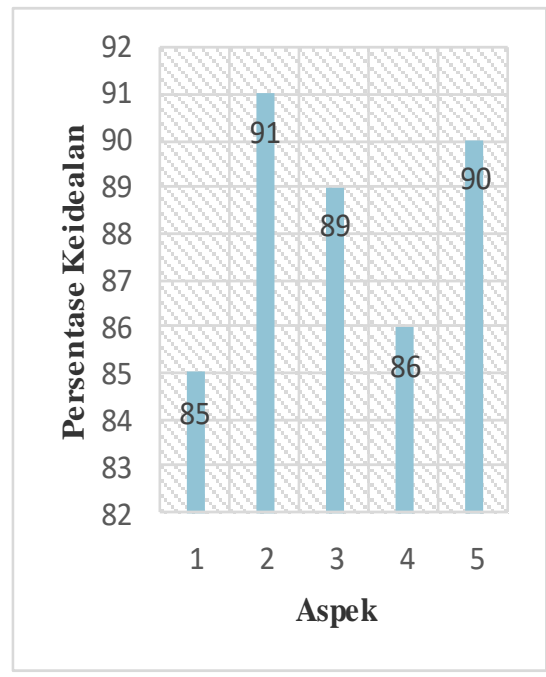

Figure 3 . Keidealan percentage of every aspect of props from the expert assessment results in material

Description:

1. Aspects of physical appearance simple props

2. Aspects of conformity simple props with the material pressure

3. Aspects of conformity curricula with simple props on the material pressure

4. Aspects of the operation and performance of the simple props

5. Aspects of the quality of the simple props

In the picture shown above, clearly visible aspect of the highest valuations in the number-two aspects that have a percentage of $91 \%$ briefly, then the fifth aspect that has a percentage of $90 \%$, the third aspect of $89 \%$, four aspects of $86 \%$ 
and the smallest on the first aspect which has a percentage of $85 \%$. Thus, the results of the assessment by the expert of the material stated that props has generated in very good quality

Assessment of every aspect on the basis of accumulated based on the percentage of each aspect can be seen in Figure 4.

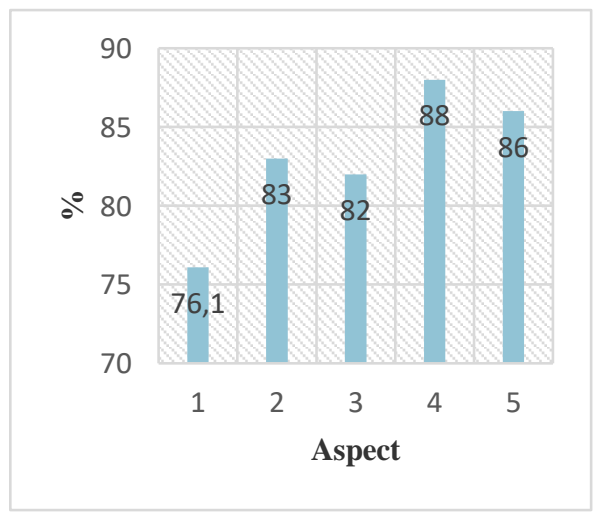

Figure 4 . Percentage of every aspect of the assessment results of the props from the peer reviewers

\section{Description:}

1. Aspects of physical appearance props

2. Aspects of conformity props with the material pressure

3. Aspects of conformity curricula with props

4. Aspects of the operation and performance of the props

5. Aspects of the quality of the props

In the figure 4, clearly visible aspects of the assessment, the highest on the number four that has a percentage $88 \%$ briefly, then the fifth aspect that has a percentage of $86 \%$, the third aspect of $83 \%$, four aspects of $82 \%$ and the smallest on the first aspect which has a percentage amounting to $76.1 \%$. Thus, the results of the assessment by the expert of the material stated that props has generated in very good quality.

Assessment of every aspect on the basis of accumulated based on the percentage of each aspect can be seen in Figure 5.

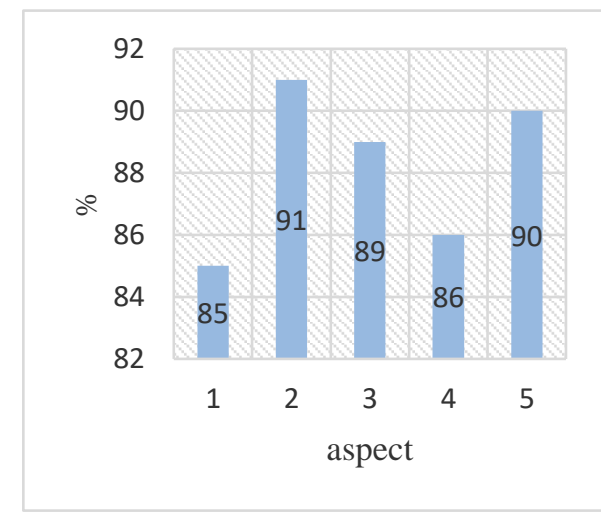

Figure 5. Percentage of every aspect of the assessment results of the props from teacher

Description:

1. Aspects of physical appearance props

2. Aspects of conformity props with the material pressure

3. Aspects of conformity curricula with props

4. Aspects of the operation and performance of the props

5. Aspects of the quality of the props

In the picture shown above, clearly visible aspect of the highest valuations in the number-two aspects that have a percentage of $91 \%$ briefly, then the fifth aspect that has a percentage of $90 \%$, the third aspect of $89 \%$, four aspects of $85 \%$ and the smallest on the first aspect which has a percentage amounting to $76.1 \%$. Thus, the results of the assessment by the expert of the material stated that props has produced excellent quality

Assessment of every aspect on the basis of accumulated based on the percentage of each aspect can be seen in Figure 6. 


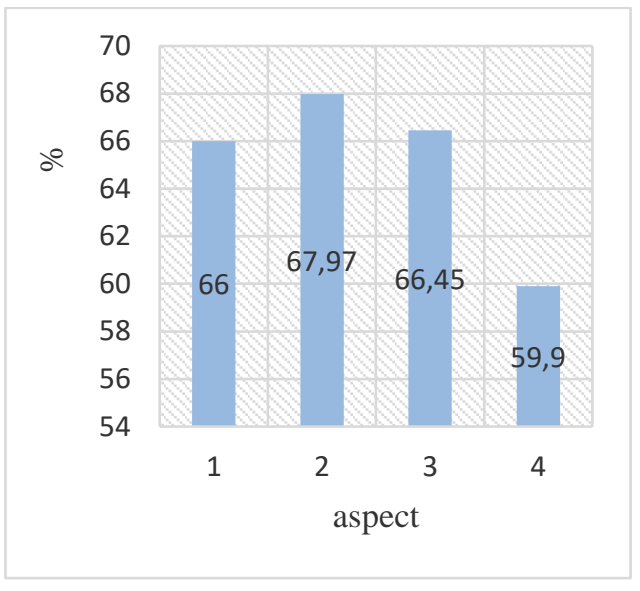

Figure 6. Percentage of every aspect of the assessment results of the props from the students.

Description:

1. Aspects Of Physical Appearance Props

2. Motivational aspects of learning with props

3. The operation and performance of the props

4. Aspects of the quality of the props

In the picture shown above, clearly visible aspects of the assessment, the highest on the number two who has briefly $67.97 \%$ percentage, then the third aspect which has a percentage of $66.45 \%$, the fourth aspect of $66 \%$, and the smallest aspects on the fourth aspect of $59.9 \%$. Thus, the results of the assessment by the expert of the material stated that props have generated in good quality. Average rating based on pretest and posttest obtained increased as much as 0.54 . Thus, the improvement of students ' critical thinking skills at the level of being. This is based on. conversion value of gain score be the qualitative data.

Research development produces Props based guided inquiry in pressure materials. Props ware developed using the model 4D i.e., Define, Design, Development and Disseminate suggested by Thiagarajan et al. (Trianto, 2014). This research only as on preparation of props and to test limited only. Stages of evaluation not only performed at the end of the study but done at every stage of the research.

Development props it has advantages i.e. develop material that refers to learning science in accordance with the concept of guided inquiry. Practical activities are presented more varied, it aims to test the student's understanding of pressure material after the experiment is presented, it also aims to increase the knowledge and critical thinking skills of students in understanding the material being presented.

Some barrier in the development of this simple props includes: 1) time: creation and validation products which takes a relatively long time. This is due to several factors, such as the respondent may be another flurry so cannot assess and provide input towards the product within the time required by the researchers. 2) Cost: in the process of making the props needed a great cost, and the difficulty of getting materials to suit the desired. and 3) researcher: the limited ability of researchers in the field of design skills specifically design props and literary language in use of language.

Rating score from reviewer response is qualitative data. Qualitative data obtained from the assessment of the reviewer are converted into quantitative data. The quantitative data are tabulated and analyzed every aspect of the assessment. The final score is obtained, converted into a level of qualitative product eligibility guidelines according to the criteria of the assessment categories are ideal.

The average score on overall assessment results based on expert media namely $99.33 \%$, expert materials namely $88.20 \%$, peer reviewers $83.02 \%$, and teachers against props i.e. $88.41 \%$ so stated good and decent to use.

Increasing critical thinking skills students are measured by pretest and 
posttest students in working on the problem of hydrostatic pressure. The number of students who follow the pretest and post test i.e. 24 students. Pretest conducted before learning begins while the posttest did after learning begins. An increase in the value of students when doing a pretest and posttest. The average value of the students when doing a pretest i.e. 5.29 and when do the posttest average students that is 7.9. Based on the gain level of critical thinking skills of students at a medium level with score 0.54 .

Based on the average value can be inferred that props can enhance critical thinking skills of students. In this study, the use of props based guided inquiry can enhance critical thinking skills of students (Permatasari, Yuanita, \& Suyono, 2014) on components provide arguments, give a simple explanation, decided on an action and conclude the results of the practical work on the material pressure of the liquid (hydrostatic pressure). The research is in line with Hartanti (2010) research regarding the development of props friction to improve critical thinking skills.

\section{Conclusions and Suggestions}

Based on the results and discussion of the research can be concluded that this development has produced simple props based guided inquiry for students of grade VIII junior high school. Development of the props using the model 4D (Define, Design, Develop, and Dissiminate) but only to the limited test only.

The quality of the simple props based guided inquiry that has been developed is good based on the research of media experts, expert content, peer reviewers, teacher assessment and student response, so the simple props based guided inquiry for grade VII worthy of learning used in science.
Development of simple props based guided inquiry can enhance critical thinking skills of students as much as 0.54 with medium criteria. It looks at acquisition average pretest and posttest students than average of 5.29 be 7.9.

Based on the results of simple props have been obtained, then the researchers suggested props is used as an alternative junior high school student learning materials grade VIII. In addition, the teacher should be able to take advantage of these props as alternative materials science on the subject of hydrostatic pressure. These props can be used on students capable of average and above as well as on the students who are capable of averaging down because this tool with instructions on the use of props to make it easier for students to study.

\section{Reference}

Asyhar, R. (2012). Kreatif Mengmbangkan Media Pembelajaran. Jakarta: Referensi Jakarta.

Dewi, N. M., dkk. (2013). Pengaruh Model Pembelajaran Inkuiri terhadap sikap ilmiah dan hasil belajar IPA. Journal Program Pascasarjana Universitas Ganesha. Jurusan Pendidikan dasar (Vol. 3)

Eggen, P dan Kauchak, D. 2012. Strategi dan Model Pembelajaran Edisi 6. Jakarta: Indeks.

Hartati, B. (2010). Pengembangan Alat Peraga Gaya Gesek Untuk Meningkatkan Keterampilan Berpikir Kritis Siswa SMATersedia:Journal.unnes.ac.idar tikel_njupdfJPFI11251045 (diakses pada tanggal 12 Desember 2016, pukul 13.00 WIB)

Ibda, F. (2017). Perkembangan Kognitif: Teori Jean Piaget. Intelektualita. (Vol. 3, No. 1) Hlm. 27-38. 
Khasanah, F dan \Octavianti, C. T. (2017).

Peningkatan Kemampuan Berpikir

Ktitis Mahasiswa Melalui

Pembelajaran SAVI dengan

Mengoptimalkan Met Eksport.

Union. Jurnal Pendidikan

Matematika (Vol. 5, No. 2) Hlm. 141-150.

Prasetyarini, A., Fatmawati, S. D., dan

Akhdini Wanto, R. W. (2013).

Pemanfaatan Alat Peraga Sederhana

IPA untuk Peningkatan Pemahaman

konsep Fisika Pada Siswa SMP

Negeri 1 Bulus Pesantren Kebumen

Tahun Pelajaran 2012/2013. Radiasi

2

(1):

7-10.

http://download.portalgaruda.org/

(diakses pada tannggal 13 Desember

2016, pukul 12.00 WIB)

Permatasari, R. E., Yuanita, L., \& Suyono, D. (2014). Implementasi Model Pembelajaran Inkuiri Terbimbing Pada Materi Sifat Koligatif Larutan. Jurnal Pena Sains, 1(2), 11-18.

Rosidi, I. (2015). Pengembangan

Perangkat Pembelajaran IPA

Terpadu Tipe Integrated Untuk

Mengetahui Ketuntasan Belajar IPA

Siswa SMP Pada Topik Pengelolaan Lingkungan. Jurnal Pena Sains, 2(1).

Shidharta A. dan Yamin, W. (2013). Pengembangan Alat Peraga Praktik (APP) IPA Sederhana untuk Guru $S M P$. Bandung: P4TK IPA.

Trianto. (2014). Mendesain Model Pembelajaran Inovatif, Progresif, dan Kontekstual: Konsep, Landasan, dan Implementasinya Pada Kurikulum 2013 (Kurikulum Tematik Integratif/TKI). Jakarta: Prenadamedia Group.

Widiyatmoko, A. (2013). Pengembangan

Perangkat Pembelajaran IPA Terpadu Berkarakter Menggunakan Pendekatan Humanistik Berbantu Alat Peraga Murah. Jurnal
Pendidikan IPA Indonesia. Vol 1 (1):76:82.

Widiyatmoko, A. dan Nurmasitah, S. (2013). Desigining Simple Teknology us a Science Teaching Aids From Used Material. Journal of Environmentally Friendly Proces, I (4): 27:31. 